\title{
PENGARUH MODEL PEMBELAJARAN GENERATIF TERHADAP PENINGKATAN SELF-CONFIDENCE SISWA DITINJAU DARI GAYA KOGNITIF
}

\section{THE INFLUENCE OF GENERATIVE LEARNING MODELS ON IMPROVING STUDENTS SELF-CONFIDENCE STUDY FROM COGNITIVE STYLE}

\author{
Sutihat $^{1}$, Hepsi Nindiasari ${ }^{2}$, Syamsuri $^{3}$ \\ ${ }^{1}$ Program Studi Pendidikan Matematika, Universitas Sultan Ageng Tirtayasa, \\ sutihat26@gmail.com \\ ${ }^{2}$ Program Studi Pendidikan Matematika, Universitas Sultan Ageng Tirtayasa, \\ hepsinindiasari@untirta.ac.id \\ ${ }^{3}$ Program Studi Pendidikan Matematika, Universitas Sultan Ageng Tirtayasa, \\ syamsuri@untirta.ac.id
}

\begin{abstract}
Abstrak
Penelitian ini bertujuan untuk mengetahui pengaruh model pembelajaran generatif terhadap peningkatan self-confidence siswa ditinjau dari gaya kognitif. Metode penelitian yang digunakan yaitu penelitian quasieksperimen dengan desain penelitian nonequivalen control group design. Populasi yang digunakan adalah seluruh siswa kelas XI MIPA di MAN 4 Tangerang tahun pelajaran 2018/2019 dengan kelas XI MIPA 2 sebagai kelas eksperimen dan kelas XI MIPA 5 sebagai kelas kontrol. Berdasarkan hasil penelitian dan analisis data diperoleh kesimpulan, (1) peningkatan selfconfidence siswa field independent yang memperoleh pembelajaran generatif lebih tinggi dari peningkatan self-confidence siswa field independent yang memperoleh pembelajaran saintifik, (2) peningkatan self-confidence siswa field dependent yang memperoleh pembelajaran generatif lebih tinggi dari peningkatan self-confidence siswa field dependent yang memperoleh pembelajaran saintifik.
\end{abstract}

Kata kunci: model pembelajaran generatif, self-confidence, gaya kognitif.

\begin{abstract}
This study aims to determine the effect of generative learning models on increasing student self-confidence in terms of cognitive style. The research method used is a quasi-experimental research with a nonequivalent control group design. The population used was all students of class XI MIPA in MAN 4 Tangerang in the academic year 2018/2019 with class XI MIPA 2 as an experimental class and class XI MIPA 5 as a control class. Based on the results of research and data analysis, it can concluded that, (1) the increase in self-confidence of independent field students who get generative learning is higher than the increase in self-confidence of independent field students who get scientific learning, (2) the increase in self-confidence of field dependent students who obtain generative learning is higher than the increase in self-confidence of field dependent students who obtain scientific learning.
\end{abstract}

Keywords: generative learning model, self-confidence, cognitive style. 


\section{PENDAHULUAN}

Matematika merupakan ilmu pengetahuan yang sangat penting untuk dipelajari pada setiap jenjang pendidikan. Seperti yang diungkapkan oleh Cockroft (Abdurrahman, 1999) bahwa matematika harus diajarkan disetiap jenjang pendidikan, karena (1) matematika selalu digunakan dalam segala segi kehidupan, (2) semua bidang studi memerlukan keterampilan matematika, (3) matematika merupakan sarana komunikasi yang kuat, singkat dan jelas. (4) matematika dapat digunakan untuk menyajikan informasi dalam berbagai cara, (5) matematika dapat meningkatkan kemampuan berpikir logis dan teliti, (6) matematika dapat digunakan untuk memecahkan masalah yang menantang.

Kurangnya rasa percaya diri dapat menyebabkan kesulitan bagi siswa untuk memahami matematika. Hal ini sejalan dengan penelitian yang dilakukan oleh Mullis dan Rahmat (Hendriana, Rohaeti, \& Sumarmo, 2017) yang mengungkapkan bahwa terdapat asosiasi positif antara kepercayaan diri dalam belajar matematika dengan hasil belajar matematika. Artinya siswa yang memiliki hasil belajar matematika tinggi juga memiliki indeks kepercayaan diri yang tinggi pula. Menurut NCTM (2000) kepercayaan diri adalah salah satu tujuan utama yang harus dicapai dalam pembelajaran. Oleh karena itu, rasa percaya diri perlu dimiliki dan dikembangan oleh setiap siswa.

Menurut James (Sarastika, 2014) self-confidence merupakan sejauh mana keyakinan terhadap penilaian diri atas kemampuan yang dimiliki dan sejauh mana Anda bisa merasakan adanya kepantasan untuk berhasil. Oleh karena itu, kepercayaan diri dapat mempengaruhi keberhasilan siswa dalam belajar. Siswa yang memiliki kepercayaan diri yang baik akan berusaha mengembangkan potensi diri secara maksimal. Sementara itu, Carol (Gestwicki, 2007) mengungkapkan:

"an important goal of primary mathematics curricula is to help children develop confidence in their ability to think things through. to assess children's confindence in math, a visitor can walk around the classroom while children are completing a worksheet and stop to ask individual children, "how did u get this answer?" (pointing to a correct answers). Many children immediately reach for their erasers indicating their lack of confidence in their own ideas"

Tujuan utama kurikulum matematika adalah untuk mengembangkan kepercayaan diri siswa atas kemampuannya. Seorang pendidik dapat membantu mengembangkan kepercayaan diri siswa dalam belajar matematika dengan cara memberikan tugas dan memberi kesempatan kepada siswa untuk bereksplorasi menemukan penyelesaian dari tugas yang diberikan serta tidak bertanya kepada siswa tentang jawaban yang diberikan secara langsung karena akan membuat siswa segera menghapus jawaban yang telah mereka berikan sehingga dapat menurunkan kepercayaan diri siswa.

Berdasarkan penelitian yang dilakukan oleh Khoo (Achdiyat, 2016), hanya sebanyak $5 \%$ siswa yang percaya diri dan berhasil, karena mereka berpikir bahwa keberhasilan adalah suatu keharusan. Sedangkan 95\% tidak percaya diri, mereka hanya berharap tanpa berpikir bahwa keberhasilan adalah suatu keharusan. Menurut Achdiyat (2016) biasanya siswa yang tidak percaya diri dikarenakan siswa memiliki pengalaman sekolah yang negatif sehingga meruntuhkan rasa percaya diri dan kecintaan alamiah mereka pada belajar. 
Pengalaman tersebut yang menyebabkan siswa takut untuk mencoba dan belajar kembali tanpa kenal putus asa.

Begitu juga dalam pembelajaran matematika, siswa cenderung membenci matematika dan terlanjur menganggap matematika itu sulit. Hal ini dikarenakan pengalaman belajar matematika disekolah cenderung membuat siswa tidak percaya diri seperti penerapan model pembelajaran yang kurang tepat dengan materi yang diajarkan. Oleh karena itu dibutuhkan model pembelajaran yang dapat meningkatkan kepercayaan diri siswa sehingga siswa tidak kesulitan dalam belajar matematika.

Model pembelajaran yang digunakan disekolah adalah model pembelajaran dengan pendekatan saintifik. Dalam pembelajaran saintifik terdapat tahap pembelajaran yang dapat meningkatkan self-confidence siswa yaitu pada tahap mengkomunikasikan. Pada tahap ini siswa diberi kesempatan untuk mempresentasikan hasil diskusi kelompok didepan kelas, dengan demikian siswa dapat memiliki rasa percaya diri tinggi. Namun kenyataan dilapangan, masih banyak siswa yang kurang percaya diri sehingga diperlukan model pembelajaran lain yang dapat meningkatkan self-confidence siswa.

Model pembelajaran yang dapat digunakan untuk meningkatkan selfconfidence siswa adalah model pembelajaran generatif karena memberikan kebebasan kepada siswa untuk mengungkapkan ide atau gagasan terhadap permasalahan yang dihadapi. Hal ini sejalan dengan pendapat Moma (2013) bahwa pembelajaran generatif akan memberikan tantangan kepada siswa untuk memecahkan suatu permasalahan matematika dan mendorong untuk lebih kreatif, termotivasi untuk belajar, percaya diri dan mendorong tumbuhnya soft skill. Selain itu, pembelajaran generatif juga memiliki tahap pembelajaran yang berbeda dengan pembelajaran saintifik yaitu adanya tahap penerapan. Pada tahap ini siswa akan menerapkan pengetahuan yang telah diperoleh dari diskusi kelompok dengan bimbingan guru untuk menyelesaikan tugas secara individu. Dengan demikian self-confidence siswa akan lebih meningkat.

Selain model pembelajaran, hal yang perlu diperhatikan dalam upaya meningkatkan self-confidence siswa adalah gaya kognitif. Gaya kognitif merupakan cara siswa yang khas dalam belajar, baik yang berkaitan dengan cara penerimaan dan pengolahan informasi, sikap terhadap informasi, maupun kebiasaan yang berhubungan dengan lingkungan belajar (Keefe, 1987). Setiap siswa memiliki gaya kognitif yang berbeda, sehingga berpengaruh terhadap kemampuan seseorang dalam menguasai materi pelajaran yang diterimanya. Selain itu, perbedaan gaya kognitif memberi konsekuensi pada penggunaan model pembelajaran yang sesuai untuk memfasilitasi perbedaan gaya kognitif tersebut. Hal ini sejalan dengan pendapat Marlissa dan Widjajanti (2015) bahwa gaya kognitif merupakan salah satu variabel kondisi belajar yang dibutuhkan untuk merancang pembelajaran. Sesuai dengan pendapat Sternberg dan Williams (2002) bahwa pendidik didorong untuk memahami perbedaan gaya kognitif agar dapat merencanakan pengajaran dengan berbagai cara. Salah satu cara untuk memfasilitasi perbedaan gaya kognitif siswa yaitu menggunakan model pembelajaran generatif.

Ada berbagai macam gaya kognitif diantaranya yaitu gaya kognitif field independence (FI) dan gaya kognitif field dependence (FD) (Witkin, Moore, Goodenough, \& Cox, 1977) Perbedaan mendasar kedua gaya kognitif tersebut 
yaitu dalam hal bagaimana melihat suatu permasalahan. Berdasarkan beberapa penelitian di bidang psikologi, ditemukan bahwa gaya kognitif field independent cenderung lebih analitis dalam melihat suatu masalah dibanding gaya kognitif field dependent.

Selain itu, perbedaan karakteristik gaya kognitif FI dan gaya kognitif FD terdapat dalam melaksanakan tugas atau menyelesaikan suatu soal, yaitu individu FI akan bekerja lebih baik jika diberi kebebasan sedangkan individu FD akan bekerja lebih baik jika diberikan petunjuk atau bimbingan secara ekstra. Seperti yang diungkapkan Skehan (1998) bahwa siswa dengan gaya kognitif FI lebih senang mencari solusi sendiri, tidak suka bergaul dan lebih senang belajar secara individual. Sedangkan siswa dengan gaya kognitid FD suka bergaul dan bekerja dengan baik dalam kelompok dan cenderung lebih banyak berinteraksi dengan orang lain.

Dengan demikian, gaya kognitif field independent dapat terfasilitasi self confidencenya dengan pembelajaran generatif karena pada pembelajaran generatif terdapat tahap penerapan dimana setiap siswa akan menerapkan kemampuan yang telah diperoleh secara individu. Begitupun untuk gaya kognitif field dependent akan terfasilitasi self confidencenya dengan pembelajaran generatif karena pada pembelajaran generatif terdapat tahap pemfokusan dan tantangan dimana siswa akan bekerja sama dengan kelompoknya untuk menyelesaikan tugas yang diberikan. Berdasarkan latar belakang masalah yang telah dipaparkan, maka tujuan dalam penelitian ini yaitu untuk mengetahui pengaruh model pembelajaran generatif terhadap peningkatan self-confidence siswa ditinjau dari gaya kognitif.

\section{KAJIAN TEORI}

\section{Self-Confidence}

Self-confidence adalah suatu sikap yakin akan kemampuan diri sendiri dan memandang diri sendiri sebagai pribadi yang utuh dengan mengacu pada konsep diri (Lestari \& Yudhanegara, 2015). Kepercayaan diri merupakan sikap positif seseorang individu yang memampukan dirinya untuk mengembangkan penilaian positif, baik terhadap diri sendiri maupun terhadap lingkungan atau situasi yang dihadapinya (Fatimah, 2010).

Menurut Lie (2003) percaya diri berarti yakin akan kemampuannya untuk menyelesaikan pekerjaan dan masalah. Ciri-ciri anak yang percaya diri yaitu, yakin kepada diri sendiri, tidak bergantung pada orang lain, tidak raguragu, merasa diri berharga, tidak menyombongkan diri, memiliki keberanian untuk bertindak. Selanjutnya, menurut Willis (Riswanti \& Ghufron, 2010) kepercayaan diri adalah keyakinan bahwa seseorang mampu menanggulangi suatu masalah dengan situasi terbaik dan dapat memberikan sesuatu yang menyenangkan bagi orang lain.

Kepercayaan diri sangat penting bagi siswa agar berhasil dalam belajar matematika. Dengan adanya rasa percaya diri, maka siswa akan lebih termotivasi dan lebih menyukai untuk belajar matematika, sehingga diharapkan prestasi matematika yang dicapai juga optimal (Yates, 2002).

Dari beberapa pendapat tentang pengertian yang telah dijelaskan oleh beberapa ahli, dapat disimpulkan bahwa kepercayaan diri adalah keyakinan seseorang terhadap kemampuan diri untuk melakukan yang terbaik dan 
berusaha mencapai tujuan dengan semaksimal mungkin serta tidak mengeluh dan berputus asa jika hasil yang diperoleh tidak sesuai harapan. Siswa yang memiliki kepercayaan diri yang tinggi akan juga memiliki kestabilan dalam belajar, tidak ragu-ragu dalam mengambil keputusan, dan selalu optimis dalam menghadapi berbagai macam keadaan yang dihadapi. Adapun indikator selfconfidence yang digunakan dalam penelitian ini yaitu indikator yang diungkapkan oleh Tamsil (Hendriana et al., 2017) antara lain, percaya pada kemampuan diri sendiri, bertindak mandiri dalam mengambil keputusan, menghargai diri dan usaha sendiri, bersemangat ketika mengemukakan pendapat dalam diskusi, dan berani menghadapi tantangan.

\section{Model Pembelajaran Generatif}

Menurut Hassard (Lusiana, Trimurti, \& Saleh, 2009) "The generative learning model is a teaching sequence based on the view that knowlegde is contructed by the learner" , maksudnya model pembelajaran generatif adalah suatu prosedur pembelajaran yang didasarkan pada suatu pandangan bahwa pengetahuan dikonstruksi oleh siswa itu sendiri. Selain itu, model pembelajaran generatif memberikan peluang dalam perkembangan daya matematika siswa melalui keluwesan berpikir secara aktif dan kreatif dalam menyelesaikan suatu permasalahan (Madio, 2012). Model pembelajaran generatif merupakan model pembelajaran berbasis konstruktivisme yang menekankan pengintegrasian secara aktif pengetahuan baru dengan pengetahuan yang dimiliki sebelumnya. Langkah-langkah pembelajaran generatif dapat menjadikan siswa aktif dalam mengkontruksi pengetahuannya. Adapun tahapan pembelajaran generatif menurut Lestari dan Yudhanegara (2015), sebagai berikut.

\section{1) Eksplorasi}

Pada tahap eksplorasi, guru membimbing siswa untuk melakukan eksplorasi terhadap pengetahuan, ide atau konsepsi awal yang diperoleh dari pembelajaran pada tingkat sebelumnya.

\section{2) Pemfokusan}

Tahap pemfokusan merupakan tahap pengenalan konsep di mana siswa melakukan pengujian hipotesis melalui kegiatan laboratorium atau kegiatan lainnya. Guru bertugas sebagai fasilitator yang menyediakan kebutuhan sumber, serta memberi bimbingan dan arahan.

\section{3) Tantangan}

Siswa berlatih untuk berani mengeluarkan ide, kritik, berdebat, menghargai pendapat teman dan menghargai adanya perbedaan pendapat. Guru berperan sebagai moderator dan fasilitator agar jalannya diskusi lebih terarah.

\section{4) Penerapan}

Pada tahap ini, siswa diajak untuk menyelesaikan masalah dengan mengaplikasikan konsep barunya pada hal-hal praktis dalam kehidupan seharihari.

\section{Model Pembelajaran dengan Pendekatan Saintifik}

Proses pembelajaran yang mengimplementasikan pendekatan saintifik akan menyentuh tiga ranah, yaitu: sikap (afektif), pengetahuan (kognitif), dan keterampilan (psikomotor). Dengan proses pembelajaran yang demikian maka diharapkan hasil belajar melahirkan peserta didik yang produktif, kreatif, inovatif, 
dan afektif melalui penguatan sikap, keterampilan, dan pengetahuan yang terintegrasi. Adapun langkah-langkah pembelajaran matematika dengan pendekatan saintifik adalah sebagai berikut:

\section{1) Mengamati}

Mengamati pada dasarnya adalah kegiatan membaca, mendengar, menyimak, melihat (tanpa atau dengan alat, dengan menggunakan indera) secara carmat untuk mengidentifikasi masalah yang ingin diketahui. Dalam pembelajaran matematika, obyek pengamatannya bisa berdasarkan fenomena matematika dan bisa juga obyek matematika itu sendiri. Pada tahapan ini, mengutamakan kebermaknaan proses pembelajaran dengan beberapa keuggulan yaitu, menyediakan obyek secara nyata, peserta didik senang dan tertantang serta mudah dalam melaksanakannya.

\section{2) Menanya}

Menanya adalah mengajukan pertanyaan tentang informasi yang tidak dipahami dari apa yang diamati atau pertanyaan untuk mendapatkan informasi tambahan tentang apa yang diamati (dimulai dari pertanyaan faktual sampai ke pertanyaan yang bersifat hipotetik). Pada tahap menanya ini guru berperan dalam membantu peserta didik merumuskan pertanyaan berdasarkan daftar hal-hal yang perlu/ingin diketahui agar dapat melakukan/menciptakan sesuatu. Ketika guru bertanya, maka pada saat ini sebenarnya dia sedang membimbing agar siswa dapat belajar dengan baik. Begitupun saat guru menjawab pertanyaan dari siswa, saat itu pula dia harus mendorong agar siswa menjadi penyimak dan pembelajar yang baik.

\section{3) Mengumpulkan Informasi}

Mengumpulkan informasi dengan berbagai teknik yang sesuai, misalnya membaca sumber lain atau buku teks, eksperimen, pengamatan, wawancara, survey, dan membaca dokumen-dokumen. Mengumpulkan informasi dalam matematika tidak terbatas pada hasil pengumpulan fakta (konkret) dari pengamatan maupun hasil percobaan, namun dapat pula dipahami sebagai pengumpulan kebenaran matematis. Seperti tentang teorema yang akan dibahas.

\section{4) Mengasosiasi}

Mengasosiasi adalah kegiatan mengolah informasi yang sudah dikumpulkan baik terbatas dari hasil kegiatan mengumpulkan atau eksperimen maupun hasil dari kegiatan mengamati, untuk menjawab pertanyaan dan menarik kesimpulan. Dengan kata lain mengasosiasi adalah mengait-ngaitkan. Artinya, peserta didik diharapkan mampu untuk mengaitkan antara fakta yang satu dengan fakta yang lain, terutama hasil penggalian informasinya, dan menemukan pola serta kesimpulannya. Pada tahap mengasosiasi ini guru berperan dalam membantu peserta didik mengolah/menganalisis data/informasi dan menarik kesimpulan. Salah satunya dengan cara memberi tugas individu atau kelompok berdasarkan materi yang telah dibahas.

\section{5) Mengkomunikasikan}

Mengkomunikasikan adalah kegiatan peserta didik menyampaikan jawaban terhadap pertanyaan berdasarkan hasil analisis informasi secara lisan, tertulis atau media lainnya. Peran guru pada tahap mengkomunikasikan ini adalah mengatur, memberi umpan balik, memberi penguatan, memberi penjelasan atau informasi lebih luas. Berdasarkan pada tahap mengasosiasi sebelumnya, yaitu peserta didik diberi tugas latihan. Maka tahap mengkomunikasikan ini peserta 
didik diminta untuk membuat kesimpulan yang sudah diperoleh pada lembar kerja atau buku tulis dan menyampaikan di depan kelas. Hasil kerja mereka bisa jadi langsung diterima atau mendapat kritik dan saran dari kelompok lain. Oleh karena itu, kegiatan mengkomunikasikan ini harus dibuat dalam suasana yang serius meskipun tetap terkesan santai dan menyenangkan.

\section{6) Gaya Kognitif}

Menurut Ausburn dan Ausburn (Singer, Voica, \& Pelezer, 2017) gaya kognitif adalah sebuah dimensi yang melukiskan konsistensi bagaimana setiap individu memproses informasi dari tugas yang berbeda. Sedangkan Kozhevnikov (Singer et al., 2017) mengungkapkan bahwa:

"In addition, a range of variables, such as intellectual abilities, previous experience, habits, and personality traits, influence the development of a particular cognitive style". Yang berarti bahwa ada beberapa hal mempengaruhi gaya kognitif, yaitu kemampuan intelektual, pengalaman sebelumnya, kebiasaan dan sifat-sifat kepribadian lainnya. Selanjutnya, Arifiyanto \& Susanah (2018) mengungkapkan bahwa gaya kognitif merupakan cara individu dalam berbagai aktivitas mental seperti berpikir, mengingat, memecahkan masalah, membuat keputusan, dan memandang atau memaknai segala permasalahan yang dihadapi.

Individu dengan gaya kognitif FD cenderung memandang sesuatu secara global dan lebih dipengaruhi oleh lingkungan sekitarnya ketika menghadapi sesuatu. Sedangkan individu dengan gaya kognitif FI cenderung lebih analitis dalam menganalisis pola, ia mampu membedakan objek-objek dari konteks sekitarnya dan tidak tergantung pada lingkungan sekitarnya. Meskipun terdapat perbedaan antara individu bergaya kognitif FD dan individu bergaya kogitif FI, tidak dapat dikatakan bahwa gaya kognitif yang satu lebih unggul dibanding gaya kognitif yang lainnya karena kedua gaya kognitif tersebut memiliki keunggulan dan kekurangannya masing-masing. Hal ini sejalan dengan pendapat Ngilawajan (2013) bahwa individu FI lebih baik dalam mengeluarkan segala kemampuannya dalam memecahkan suatu masalah ketika ia diberi kebebasan. Sedangkan individu FD dapat menggunakan seluruh kemampuannya semaksimal dan sefektif mungkin dalam memecahkan masalah ketika ia diberi petunjuk atau arahan yang jelas.

\section{METODE PENELITIAN}

Penelitian ini merupakan penelitian quasi-eksperimen karena pada penelitian ini subjek tidak dikelompokkan secara acak, tetapi penelitian menerima keadaan subjek apa adanya (Ruseffendi, 2010). Penggunaan desain dilakukan dengan pertimbangan bahwa kelas yang ada telah terbentuk sebelumnya, sehingga tidak dilakukan lagi pengelompokkan secara acak. Pembentukan kelas baru hanya akan menyebabkan kacaunya jadwal pelajaran yang telah terjadwal di sekolah tersebut.

Desain penelitian yang digunakan dalam penelitian ini melibatkan dua kelompok yaitu kelompok eksperimen dan kelompok kontrol. Model desain penelitian yang digunakan adalah nonequivalen control group design, dalam desain ini kelompok eksperimen maupun kelompok kontrol tidak dipilih secara random (Sugiyono, 2010). Baik kelas ekperimen maupun kelas kontrol, keduanya diberi pretest dan postest yang sama yaitu dengan menggunakan 
skala self-confidence. Sebelum diberikan pretest skala self-confidence siswa pada kelompok eksperimen maupun kelas kontrol diberikan tes penggolongan gaya kognitif untuk mengetahui gaya kognitif dari setiap siswa. Adapun materi yang diajarkan baik dikelas eksperimen maupun kelas kontrol yaitu materi integral. Pemberian materi pada kelas eksperimen dan kelas kontrol dilakukan agar dapat melihat pengaruh model pembelajaran terhadap self-confidence siswa.

\section{Populasi dan Sampel Penelitian}

Populasi dalam penelitian ini adalah seluruh siswa kelas XI MIPA semester 2 MAN 4 Tangerang tahun pelajaran 2018/2019 yang tersebar ke dalam 5 kelas. Teknik pengambilan sampel dalam penelitian ini diambil dengan teknik cluster random sampling, yaitu dengan mengambil dua kelas dari populasi secara acak (diundi) dengan syarat populasi harus normal dan homogen. Adapun kelas yang digunakan sebagai sampel dalam penelitian ini yaitu, kelas XI MIPA 2 sebagai kelas eksperimen yang mendapatkan pembelajaran generatif dan kelas XI MIPA 5 sebagai kelas kontrol yang mendapatkan pembelajaran saintifik dimana masing-masing kelas terdiri dari 26 siswa.

\section{Tes Penggolongan Gaya Kognitif Siswa}

Instrumen gaya kognitif dibuat dengan tujuan untuk dapat mengelompokkan siswa yang memiliki gaya kognitif field independent dan siswa yang memiliki gaya kognitif filed dependent dan diberikan sebelum pelaksanaan penelitian. Instrumen yang digunakan untuk mengukur gaya kognitif siswa dalam penelitian ini adalah Group Embedded Figure Test (GEFT). Adapun pedoman penskoran yang digunakan dalam penelitian ini sebagai berikut.

Tabel 1. Pedoman Penskoran Gaya Kognitif Siswa

\begin{tabular}{ccc}
\hline $\begin{array}{l}\text { Jenis Kelamin } \\
\text { Gaya Kognitif }\end{array}$ & Perempuan & Laki-laki \\
\hline Field Dependent & $0-11$ & $0-12$ \\
\hline Field Independent & $12-18$ & $13-18$ \\
\hline
\end{tabular}

\section{Instrumen Self Confidence}

Instrumen yang digunakan untuk mengukur self-confidence siswa dalam penelitian ini adalah instrumen baku yang telah divalidasi oleh Tamsil (Hendriana et al., 2017) sehingga tidak perlu dilakukan uji coba terhadap instrumen tersebut. Sebelum digunakan dalam penelitian, instrumen selfconfidence terlebih dahulu divalidasi teoritik oleh dosen pendidikan matematika dan guru pelajaran matematika. Selanjutnya instrumen diberikan kepada kelas eksperimen dan kelas kontrol. Instrumen self-confidence diberikan sebanyak dua kali, yaitu pretest untuk mengetahui self-confidence siswa dan posttest untuk mengetahui self-confidence siswa setelah pembelajaran. 


\section{Teknik Analisis Data}

Data hasil skala self-confidence diperoleh dari pretest dan posttest. Oleh karena itu, sebelum melakukan pengujian hipotesis perlu dilakukan perhitungan $\mathrm{N}$-Gain skor. Pengujian hipotesis dalam penelitian ini digunakan teknik analisis varians (ANOVA) dua jalur. Sebelum menguji hipotesis, terlebih dahulu dilakukan pengujian prasyarat analisis yaitu uji normalitas data dan uji homogenitas data. Uji normalitas menggunakan uji chi kuadrat dan uji homogenitas menggunakan uji Lavene's test of equality of eror variances.

\section{HASIL DAN PEMBAHASAN}

\section{Tes Penggolongan Gaya Kognitif}

Dari hasil pengisian instrumen gaya kognitif yang telah dilakukan oleh siswa baik pada kelas eksperimen maupun kelas kontrol diperoleh data seperti pada Tabel 2 berikut.

Tabel 2. Sebaran Siswa Berdasar Gaya Kognitif

\begin{tabular}{c|ccc}
\hline Kelas & Gaya Kognitif & Jumlah Siswa & Total \\
\hline Eksperimen & FI & 8 & 26 \\
& FD & 18 & \\
\multirow{2}{*}{ Kontrol } & FI & 13 & 26 \\
& FD & 13 & \\
\hline
\end{tabular}

Penelitian dilakukan pada kelas yang memiliki jumlah siswa yang sama yaitu sebanyak 26 orang. Dari Tabel 4 diperoleh gaya kognitif untuk kelas eksperimen yang mendapatkan pembelajaran generatif terdiri dari siswa dengan gaya kognitif FI sebanyak 8 orang dan siswa dengan gaya kognitif FD sebanyak 18 orang. Sedangkan untuk kelas kontrol yang mendapatkan pembelajaran saintifik terdiri dari siswa dengan gaya kognitif FI sebanyak 13 orang dan siswa dengan gaya kognitif FD sebanyak 13 orang.

\section{Skala Self-Confidence}

Berikut ini adalah hasil perhitungan N-Gain skor dalam bentuk persen yang diperoleh disajikan pada Tabel 3 berikut.

Tabel 3. Statistik Deskriptif Presentase Skor N-Gain Self Confidence

\begin{tabular}{l|llllllll}
\hline $\begin{array}{c}\text { Kelas/ } \\
\text { Gaya } \\
\text { Kognitif }\end{array}$ & $\begin{array}{c}\text { Genera } \\
\text { tif }\end{array}$ & $\begin{array}{c}\text { Sainti } \\
\text { fik }\end{array}$ & FI & FD & $\begin{array}{c}\text { Generat } \\
\text { if FI }\end{array}$ & $\begin{array}{c}\text { Generati } \\
\boldsymbol{f F D}\end{array}$ & $\begin{array}{c}\text { Saintifi } \\
\boldsymbol{k} \boldsymbol{F I}\end{array}$ & $\begin{array}{c}\text { Saintifik } \\
\boldsymbol{F D}\end{array}$ \\
\hline N & 26 & 26 & 21 & 31 & 8 & 18 & 13 & 13 \\
Mean & 10,05 & $-2,52$ & 2,49 & 4,63 & 6,09 & 11,81 & 0,27 & $-5,31$ \\
SD & 21,88 & 10,24 & 13,9 & 20,6 & 21,07 & 22,60 & 7,00 & 12,34 \\
& & & 0 & 0 & & & & \\
Min & -42 & -43 & -24 & -43 & -24 & -42 & -11 & -43 \\
Max & 57 & 16 & 45 & 57 & 45 & 57 & 16 & 5 \\
\hline
\end{tabular}

Dari Tabel 5, diperoleh presentase skor N-Gain self-confidence yaitu nilai rata-rata untuk kelas generatif sebesar $10,05 \%$, nilai rata-rata untuk kelas 
saintifik sebesar $-2,52 \%$, nilai rata-rata untuk gaya kognitif FI sebesar 2,49\%, nilai rata-rata untuk gaya kognitif $\mathrm{FD} 4,63 \%$, nilai rata-rata untuk kelas generatif dengan gaya kognitif FI sebesar $6,09 \%$, nilai rata-rata untuk kelas generatif dengan gaya kognitif FD sebesar $11,81 \%$, nilai rata-rata untuk kelas saintifik dengan gaya kognitif FI sebesar $0,27 \%$ dan nilai rata-rata untuk kelas saintifik dengan gaya kognitif FD sebesar -5,31. Data tersebut dapat disajikan dalam bentuk Diagram 1 berikut.

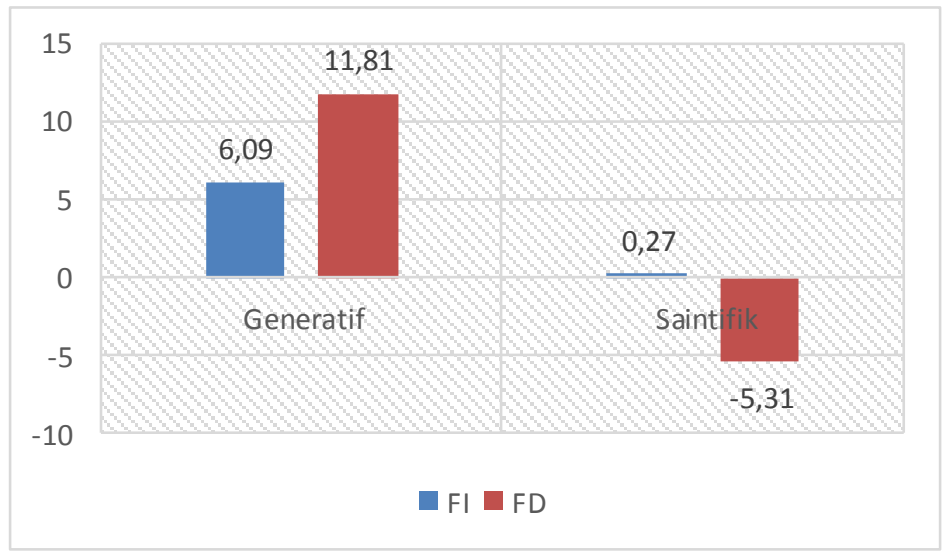

Diagram 1. Hasil N-Gain Self-Confidence

Dari Diagram 1 terlihat rata-rata hasil $\mathrm{N}$-Gain self-confidence untuk kelas generatif dengan kelas saintifik berdasarkan gaya kognitif berbeda secara signifikan.

Berdasarkan hasil uji normalitas dan uji homogenitas, maka data selfconfidence dapat disusun pada tabel analisis ANOVA dua jalur (Two Way Anova). Hasil analisis ANOVA dua jalur (Two Way Anova) self-confidence disajikan dalam Tabel 4 berikut.

Tabel 4. Analisis Varians (ANOVA) Dua Jalur Self Confidence

\begin{tabular}{lccccc}
\hline \multicolumn{1}{c}{ Sumber Varians } & $\begin{array}{c}\text { Jumlah } \\
\text { Kuadrat }\end{array}$ & $\begin{array}{c}\text { Db } \\
\text { Rata-rata Jumlah } \\
\text { Kuadrat }\end{array}$ & $\begin{array}{c}\text { Fhitun Ftabel } \\
\text { g }\end{array}$ & \\
\hline Antar A & 1574,141 & 1 & 1574,141 & 5,318 & 4,04 \\
\hline Antar B & 0,051 & 1 & 0,051 & 0,000 & 4,04 \\
\hline Antar A* Antar B & 381,932 & 1 & 381,932 & 1,290 & 4,04 \\
\hline Dalam & 14209,113 & 48 & & & \\
\hline Total & 16647,172 & 51 & & & \\
\hline
\end{tabular}

Dari Tabel 4 diperoleh $F_{\text {hitung }}$ untuk model pembelajaran dan gaya kognitif sebesar 1,290 lebih kecil dari $F_{\text {tabel }}$ yaitu 4,04, maka $H_{o}$ diterima. Sehingga tidak terdapat interaksi model pembelajaran dan gaya kognitif terhadap peningkatan self confidence. Karena tidak terdapat interaksi model pembelajaran dan gaya kognitif terhadap peningkatan self confidence, maka dapat disimpulkan bahwa peningkatan self-confidence siswa dengan gaya kognitif field independent dan field dependent yang memperoleh pembelajaran generatif lebih tinggi dari peningkatan self-confidence siswa dengan gaya kognitif field independent dan field dependent yang memperoleh pembelajaran saintifik. Hal ini juga dapat dilihat dari Gambar 1, yaitu peningkatan self- 
confidence pada pembelajaran generatif terlihat lebih tinggi dari pembelajaran saintifik berdasarkan gaya kognitif.

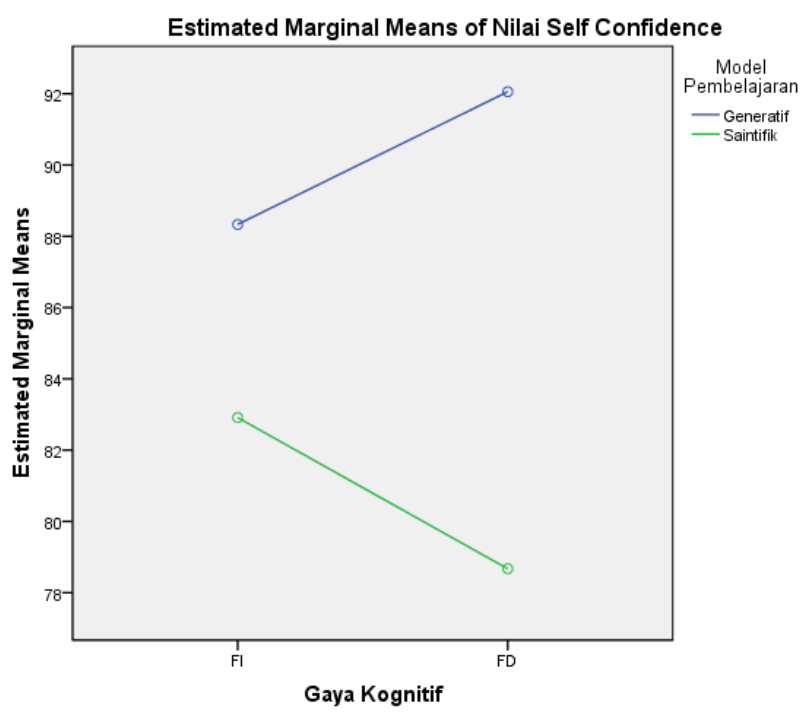

Gambar 1. Interaksi Antara Model Pembelajaran dan Gaya Kognitif Siswa pada Self-Confidence

Menurut Setiawan (2014) self-confidence adalah kondisi mental atau psikologis seseorang, dimana individu dapat mengevaluasi keseluruhan dari dirinya sehingga memberi keyakinan kuat pada kemampuan dirinya untuk melakukan tindakan dalam mencapai berbagai tujuan didalam hidupnya. Adapun indikator self-confidence yang digunakan dalam penelitian ini adalah indikator yang diungkapkan oleh Tamsil (Hendriana et al., 2017) diantaranya, (1) percaya pada kemampuan diri sendiri, (2) bertindak mandiri dalam mengambil keputusan, (3) menghargai diri dan usaha sendiri, (4) bersemangat ketika mengemukakan pendapat dalam diskusi, dan (5) berani menghadapi tantangan. Dalam penelitian ini self-confidence siswa baik pada kelas eksperimen maupun kelas kontrol ditinjau dari gaya kognitif siswa yaitu gaya kognitif field independent dan gaya kognitif field dependent.

Berdasarkan Gambar 1 menunjukkan bahwa tidak ada interaksi antara model pembelajaran dan gaya kognitif terhadap self-confidence siswa. Hal ini berarti self-confidence siswa pada model pembelajaran generatif meningkat lebih baik daripada pembelajaran saintifik, namun tidak bergantung pada gaya kognitifnya.

Selanjutnya, berdasarkan analisis data dalam tabel ANOVA dua jalur diperoleh kesimpulan bahwa peningkatan self-confidence siswa field independent dan siswa field dependent pada pembelajaran generatif lebih tinggi dari siswa field independent dan siswa field dependent pada pembelajaran saintifik. Hal ini dikarenakan model pembelajaran generatif dapat memberikan kebebasan kepada siswa untuk mengungkapkan ide atau gagasan terhadap permasalahan yang dihadapi baik secara individu maupun kelompok. Sejalan dengan pendapat Moma (2013) bahwa pembelajaran generatif akan memberikan tantangan kepada siswa untuk memecahkan suatu permasalahan matematika dan mendorong untuk lebih kreatif, termotivasi untuk belajar, 
percaya diri dan mendorong tumbuhnya soft skill. Hal ini juga sesuai dengan karakteristik siswa field independent dan field dependent yang diungkapkan oleh Frank (1986) bahwa gaya kognitif FI lebih memilih memecahkan masalah sendiri, sedangkan gaya kognitif FD lebih memilih mengerjakan tugas secara berkelompok.

Pada pembelajaran generatif siswa field independent dapat lebih mengembangkan self-confidence nya pada tahap penerapan. Pada tahap ini siswa diberikan kebebasan untuk mengerjakan tugas secara individu sehingga siswa field independent dapat memaksimalkan kemampuannya lebih baik lagi. Sedangkan siswa field dependent dapat lebih mengembangkan self-confidence nya pada tahap pemfokusan dan tantangan. Pada tahap ini siswa diberikan kebebebasan untuk mengeksplor kemampuannya dengan berdiskusi secara kelompok dan mempresentasikan hasil diskusi di depan kelas sehingga siswa field independent dan field dependent dapat mengembangkan self-confidence nya. Dengan demikian, model pembelajaran generatif dapat meningkatkan selfconfidence ditinjau dari gaya kognitif.

Adapun untuk mengetahui perbedaan self-confidence siswa FI dan FD pada pembelajaran generatif dapat dilihat dari nilai rata-rata setiap indikator self-confidence yang diperoleh pada saat pretest dan posttest. Berikut ini disajikan rata-rata pretest skala self-confidence pada pembelajaran generatif berdasarkan indikator dalam Diagram 2 berikut.

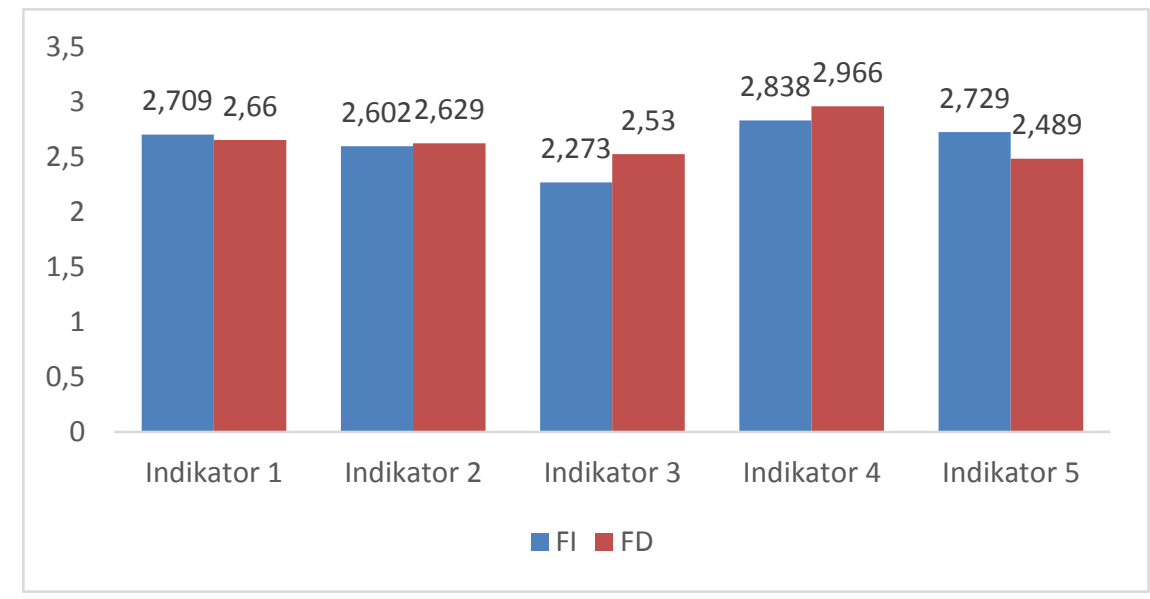

Diagram 2. Rata-rata Pretest Indikator Self-Confidence

Dari Diagram 2, dapat dilihat bahwa siswa FI memiliki nilai rata-rata pretest yang tinggi pada indikator 1 dan 5. Sedangkan siswa FD memiliki nilai rata-rata pretest yang tinggi pada indikator 2, 3, 4. Hal ini menunjukkan bahwa pada awal pembelajaran self-confidence siswa FD lebih tinggi dari siswa FI.

Siswa FD memiliki hubungan interpersonal yang lebih baik dari siswa FD sehingga self-confidence siswa FD dapat lebih baik dari siswa FI. Hal ini sejalan dengan pendapat Hidayat, et al. (2013) gaya kognitif FI cenderung kurang begitu tertarik dengan fenomena sosial, lebih suka dengan ide-ide dan prinsip-prinsip yang abstrak, kurang hangat dalam hubungan interpersonal. Sementara itu, gaya kognitif FD dikategorikan sebagai seorang yang dapat berpikir secara global, berperilaku sensitif secara sosial dan berorientasi interpersonal. 
Selanjutnya, rata-rata posttest self-confidence pada pembelajaran generatif berdasarkan indikator disajikan dalam Diagram 3 berikut.

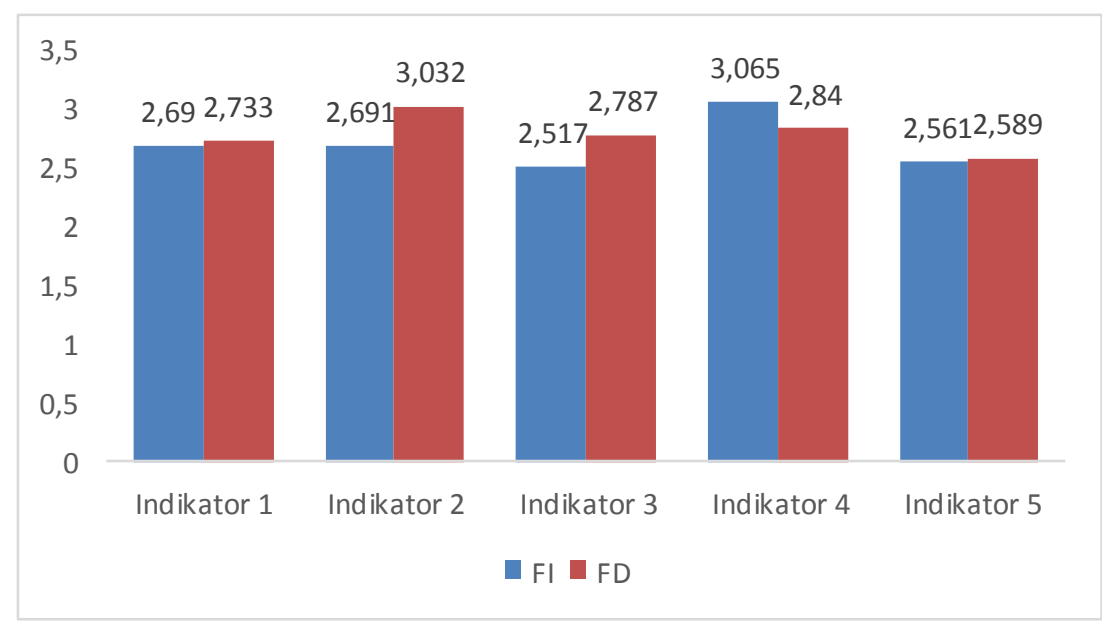

Diagram 3. Rata-rata Posttest Indikator Self Confidence

Dari Diagram 3, dapat dilihat bahwa rata-rata self-confidence siswa FI dan siswa FD mengalami peningkatan, namun siswa FD memiliki nilai rata-rata posttest yang lebih tinggi dari siswa FI pada indikator 1, 2, 3 dan 5. Hal ini menunjukkan bahwa pada akhir pembelajaran generatif self-confidence siswa FD lebih tinggi dari siswa FI.

Dari rata-rata postest setiap indikator self-confidence menunjukkan siswa FD memiliki self-confidence yang lebih baik dari pada siswa FI. Hal ini dikarenakan dalam pembelajaran generatif terdapat diskusi kelompok yang mampu mengembangkan self-confidence siswa FD sesuai dengan karakteristiknya, yaitu dapat bekerja lebih baik dalam kegiatan kelompok. Sejalan dengan pendapat Skehan (1998) bahwa siswa dengan gaya kognitif FD suka bergaul dan bekerja dengan baik dalam kelompok.

\section{SIMPULAN DAN SARAN}

Berdasarkan hasil penelitian terlihat bahwa peningkatan self-confidence siswa field independent dan field dependent pada pembelajaran generatif lebih tinggi dari siswa field independent dan field dependent pada pembelajaran saintifik. Dengan demikian, model pembelajaran generatif dapat berpengaruh terhadap peningkatan self-confidence siswa ditinjau dari gaya kognitif.

Dari kesimpulan yang diperoleh, peneliti memberikan saran untuk penelitian berikutnya agar menerapkan pembelajaran generatif untuk meningkatkan kemampuan kognitif maupun afektif lain berdasarkan tinjauan dan materi yang berbeda agar dapat menambah pengetahuan untuk peneliti sendiri maupun untuk lingkungan. Selain itu, untuk para guru agar dapat memaksimalkan potensi peserta didiknya dengan memberikan model pembelajaran yang dapat mengembangkan self-confidence siswa sesuai dengan gaya kognitifnya. 


\section{DAFTAR RUJUKAN}

Abdurrahman, M. (1999). Pendidikan Bagi Anak Berkesulitan Belajar. Jakarta: Rineka Cipta.

Achdiyat, M. (2016). Hasil Belajar Matematika ditinjau dari Model Pembelajaran Teams Assisted Individualization (TAI). Formatif : Jurnal Ilmiah Pendidikan MIPA, 6(3), 246-255. https://doi.org/10.30998/formatif.v6i3.996

Arifiyanto, Y., \& Susanah. (2018). Profil Berpikir Reflektif Siswa dalam Memecahkan Masalah Matematika ditinjau dari Gaya Kognitif Field Dependent dan Field Independent. Mathedunesa: Jurnal Ilmiah Pendidikan Matematika, 7(3), 594-599.

Danili, E., \& Reid, N. (2006). Cognitive Factors That Can Potentially Affect Pupils' Test Performance. Retrieved from http://www.rsc.org/images/DaniliReid final_tcm18-52108.pdf.

Fatimah, E. (2010). Psikologi Perkembangan. Bandung: Pustaka Setia.

Frank, B. M. (1986). Cognitive Styles and Teacher Education: Field Dependence and Areas of Specialization among Teacher Education Majors. The Journal of Educational Research, 80(1), 19-22.

Gestwicki, C. (2007). Developmentally Appropriate Practice. Canada: Thomson Delmar Learning.

Hendriana, H., Rohaeti, E. E., \& Sumarmo, U. (2017). Hard Skills dan Soft Skills Matematik Siswa. Bandung: PT. Refika Aditama.

Hidayat, B. R., Sugiarto, B., \& Pramesti, G. (2013). Analisis Kesalahan Siswa dalam Menyelesaikan Soal pada Materi Ruang Dimensi Tiga ditinjau dari Gaya Kognitif Siswa. Jurnal Pendidikan Matematika Solusi, 1(1), 39-46.

Keefe, J. W. (1987). Learning Style Theory and Practice. Virginia: NASSP Association driven.

Lestari, K. E., \& Yudhanegara, M. R. (2015). Penelitian Pendidikan Matematika. Bandung: PT. Refika Aditama.

Lie, A. (2003). 101 Cara Menumbuhkan Percaya Diri Anak. Jakarta: Elex Media Komputindo.

Lusiana, Trimurti, H., \& Saleh, T. (2009). Penerapan Model Pembelajaran Generatif untuk Pelajaran Matematika di Kelas X SMA Negeri 8 Palembang. Jurnal Pendidikan Matematika, 3(2), 29-47.

Madio, S. S. (2012). Model Pembelajaran Generatif dalam Upaya Meningkatkan Hasil Belajar Matematika. Mosharafa, 1, 29-33.

Marlissa, I., \& Widjajanti, D. B. (2015). Pengaruh Strategi REACT ditinjau dari Gaya Kognitif Terhadap Kemampuan Pemecahan Masalah, Prestasi Belajar dan Apresiasi Siswa Terhadap Matematika. Jurnal Riset Pendidikan Matematika, 2(2), 186-196.

Moma, L. (2013). Menumbuhkan Soft Skill Siswa dalam Pembelajaran Matematika Melalui Pembelajaran Generatif. Dalam Penguatan Peran Matematika dan Pendidikan Matematika untuk Indonesia yang Lebih Baik (387-396). Yogyakarta: Seminar Nasional Matematika dan Pendidikan Matematika FMIPA UNY.

NCTM. (2000). Principles and Standards for School Mathematics. Reston, Virginia.: NCTM. 
Ngilawajan, D. A. (2013). Proses Berpikir Siswa SMA dalam Memecahkan Masalah Matematika Materi Turunan ditinjau dari Gaya Kognitif Field Independent dan Field Dependent. Pedagogia, 2(1), 71-83.

Riswanti, R., \& Ghufron, M. N. (2010). Teori-teori Psikologi. Yogyakarta: ArRuzz Media Grup.

Ruseffendi, E. T. (2010). Dasar-dasar Penelitian Pendidikan \& Bidang NonEksakta Lainnya. Bandung: Tarsito.

Sarastika, P. (2014). Buku Pintar Tampil Percaya Diri. Yogyakarta: Araska.

Setiawan, P. (2014). Siapa Takut Tampil Percaya Diri? Yogyakarta: Parasmu.

Singer, F. M., Voica, C., \& Pelezer, I. (2017). Cognitive Styles in Posing Geometry Problems: Implications for Assessment of Mathematical Creativity. ZDM Mathematics Education, 49, 37-52. https://doi.org/DOI 10.1007/s11858-016-0820-x

Skehan, P. (1998). A Cognitive Approach to Language Learning (Oxford Applied Linguistics). Oxford: Oxford University Press.

Sternberg, R. J., \& Williams, W. M. (2002). Educational Psychology. Boston: Allyn and Bacon.

Sugiyono. (2010). Metode Penelitian Pendidikan (Pendekatan Kuantitatif, Kualitatif, dan $R \& D)$. Bandung: Alfabeta.

Witkin, H. A., Moore, C. A., Goodenough, D. R., \& Cox, P. W. (1977). FieldDependent and Field-Independent Cognitive Style and Their Educational Implications. JSTOR, 47(1), 1-64.

Yates, S. M. (2002). The Influence of Optimism and Pessimism on Student Achievement in Mathematics. Mathematics Education Research Journal, 14, 4-15. 